BIOFARM

Jurnal Ilmiah Pertanian

ISSN Print: 0216-5430; ISSN Online: 2301-6442

Vol. 14, No. 2, Oktober 2018

\title{
Pengaruh Umur Panen dan Lama Penyulingan terhadap Hasil Minyak Atsiri Sereh Wangi (Cymbopogon nardus L.)
}

\author{
Effect of Harvest Age and Distillation Length on the Results of Citronella \\ Fragrant Essential Oil (Cymbopogon nardus L.)
}

\author{
Mukhammad Yafik Khusna* dan Pudjiati Syarif \\ Program Studi Agroteknologi, Fakultas Pertanian, Universitas Pekalongan \\ *Korespondensi Penulis: yafikdavinsi@gmail.com
}

\begin{abstract}
ABSTRAK
Sereh Wangi (Cymbopogon nardus L.) merupakan tanaman golongan rumput-rumputan yang mempunyai nilai ekonomi karena kandungan minyak atsirinya. Penelitian bertujuan mengetahui Pengaruh Umur Panen dan Lama Penyulingan terhadap hasil Minyak Atsiri Sereh Wangi. Percobaan dilaksanakan di PTPN IX Siluwok Subah Kab. Batang. Rancangan percobaan yang digunakan adalah RAL. Faktor pertama Umur Panen terdiri atas (U1 Umur 3 bulan, U2 Umur 4 bulan, U3 Umur 5 bulan) faktor kedua Lama Penyulingan (P1 4 jam, P2 5 jam, P3 6 jam ). Variabel yang diamati meliputi tingkat kekentalan, warna, aroma, rendemen, bobot jenis, kelarutan dalam alkohol $70 \%$, kadar sitral, kebutuhan air untuk uap dan bahan bakar. Hasil penelitian menunjukan Umur Panen berpengaruh sangat nyata terhadap variabel warna, bobot jenis dan kelarutan dalam alkohol $70 \%$. Hasil paling baik yaitu umur panen 3 bulan (U1). Lama Penyulingan berpengaruh sangat nyata terhadap tingkat kekentalan, kebutuhan air untuk uap, bahan bakar dan berbeda nyata pada variabel aroma, rendemen dan kadar sitral. Lama Penyulingan paling efisien adalah lama penyulingan 5 jam (P2). Interaksi antara Umur Panen dan Lama Penyulingan menunjukkan hasil berbeda sangat nyata pada variabel tingkat kekentalan, warna, rendemen, bobot jenis, kelarutan dalam alkohol $70 \%$ dan kadar sitral dan berbeda nyata pada variabel aroma, kebutuhan air untuk uap dan bahan bakar. Interaksi terbaik yaitu umur panen 3 bulan dan lama penyulingan 5 jam (U1P2).
\end{abstract}

Kata kunci: sereh wangi, umur panen, lama penyulingan

ABSTRACT

Citronella (Cymbopogon nardus L.) is a grassroots plant that has economic value because of its essential oil content. The objective of this research is to know the influence of Harvesting Age and Old Distillation on the yield of Essential Oil of Citronella. The experiment was conducted at PTPN IX Siluwok Subah kab. Batang. The experiment design used is RAL. The first factor of Harvest Age consists of (U1 Age 3 months, U2 Age 4 months, U3 Age 5 months) Second factor Distillation Time (P1 4 hours, P2 5 hours, P3 6 hours). Observation variables include the level of viscosity, colour, flavour, rendement, weight of type, solubility in $70 \%$ alcohol, citral level, water requirement for steam, fuel. The results showed that Harvest Age had a very significant effect on color variables, species weight and solubility in $70 \%$ alcohol. The best result is 3 months of harvest (U1). The duration of distillation has significant effect on viscosity level, water demand for steam, fuel and significantly different on flavour, rendement and citral variables. The most efficient refining duration is 5 hours (P2). The interaction between Harvest Age and the Distillation Period showed very different results on variables of viscosity, color, yield, species weight, $70 \%$ alcohol solubility and citral content and significantly different in flavour variables, water requirement for steam and fuel. The best interaction is 3 month harvest age and 5 hours distillation time (U1P2).

Keywords: citronella, harvest age, old distillery

\section{PENDAHULUAN}

Tanaman sereh wangi termasuk golongan rumput-rumputan yang disebut Andropogon nardus atau Cymbopogon nardus. Genus ini meliputi hampir 80 species, tetapi hanya beberapa jenis yang menghasilkan minyak atsiri yang mempunyai arti ekonomi dalam dunia perdagangan (Santoso, 1992).

Sereh wangi (cymbopogon nardus L) merupakan salah satu tanaman atsiri dari famili Gramineae yang telah dikenal di Indonesia sejak sebelum Perang Dunia II. Di dunia perdagangan minyak ini dikenal dengan Java citronella oil, dan banyak digunakan dalam berbagai industri parfum, kosmetik, makanan, minuman dan obatobatan (Rosman, 2012).

Kebutuhan minyak atsiri dunia semakin tahun semakin meningkat seiring dengan 
meningkatnya perkembangan industri modern seperti industri parfum, kosmetik, makanan, aroma terapi dan obat-obatan (Richards, 1944). Produksi minyak sereh wangi Indonesia pada tahun tujuh puluhan pernah kesohor dengan julukan "Jawa Citronella", namun beberapa tahun terakhir ini terus menunjukkan penurunan, tahun 1983 volume ekspor sitronella masih rendah, yaitu sekitar $328.567 \mathrm{~kg}$, lalu tahun berikutnya naik sedikit menjadi $418.615 \mathrm{~kg}$ dan tahun 1987 menjadi $307.280 \mathrm{~kg}$ dengan nilai 2 juta dolar AS (Ambarwati, 2013).

Mutu minyak sereh dipengaruhi oleh karakter daun dan metode penyulingannya. Karakter daun sangat ditentukan oleh kesuburan tanah, umur tanaman dan perlakuan pertama pada daun sereh wangi tersebut. Pelayuan bahan sebelum disuling berpengaruh terhadap randemen minyak (Sebayang, 2011). Tanaman sereh yang telah berumur kurang lebih enam bulan, biasanya mulai dapat dipotong. Bagian yang paling banyak mengandung minyak adalah daun, maka daun sereh harus dipotong diatas bagian batang. Saat pemotongan pilih sereh jangan sampai sereh mulai berbunga, karena akan menyebabkan daun pada bagian tengah rumpun menjadi kuning dan bagian pinggir akan mengering sehingga mengakibatkan kandungan geraniol dan sitronella menurun yang menjadikan mutu minyak atsiri sereh wangi menurun. Pemotongan daun dapat dilakukan tiaptiap 2-3 bulan sekali setelah panen pertama 6 bulan (Ketaren, 1985).

Penyulingan adalah proses pemisahan komponen yang berupa cairan atau padatan dari 2 macam campuran atau lebih berdasarkan perbedaan titik uapnya dan proses ini dilakukan terhadap minyak atsiri yang tidak larut dalam air (Ketaren, 1985). Penyulingan secara tidak langsung, yaitu dengan cara memisahkan penguapan air dengan penguapan minyak. Bahan tumbuhan diletakkan di tempat tersendiri yang dialiri uap air, atau secara lebih sederhana bahan tumbuhan di letakkan di atas air mendidih (Harris, 1987).

Pada prinsipnya semakin lama proses penyulingan maka semakin banyak uap air yang kontak dengan bahan sehingga minyak yang teruapkan semakin besar jumlahnya. Lama penyulingan yang optimal dapat ditentukan dengan mengetahui jumlah minyak yang sudah tersuling pada setiap penambahan waktu tertentu dengan memperhatikan tetesan embun yang keluar dari kondensor. Kecilnya rendemen yang diperoleh, diduga karena banyaknya minyak dari kondensor yang melayang dalam air dan menempel pada dinding dan dasar wadah penampung destilat sehingga ada minyak yang terbuang (Novalny, 2006).

Berdasarkan pengalaman pada penyulingan 4,5 jam akan menghasilkan minyak sereh wangi dengan kadar geraniol maksimum $85 \%$ dan sitronella $35 \%$. Dengan demikian penyulingan diatas 4,5 jam (5-6) jam tidak akan menambah kadar kedua zat tersebut. Lama penyulingan tergantung dari tekanan uap yang dipergunakan dan faktor kondisi terutama kadar air daun sereh (Sebayang, 2011). Penelitian ini dilakukan dengan tujuan untuk mengetahui pengaruh umur panen terhadap kualitas dan rendemen minyak Atsiri, mengetahui lama penyulingan yang paling efisien terhadap rendemen minyak atsiri yang dihasilkan dan mengetahui interaksi antara umur panen dan lama penyulingan yang memberikan hasil terbaik terhadap kualitas dan rendemen minyak atsiri.

\section{BAHAN DAN METODE}

Percobaan ini telah dilaksanakan di PTPN IX Siluwok Subah pada bulan April-Mei 2017. Penelitian ini menggunakan rancangan acak lengkap (RAL). Faktor pertama yaitu pengaruh umur panen dengan tiga taraf yang terdiri atas U1 (Umur Panen 3 bulan), U2 (Umur Panen 4 bulan) dan U3 (Umur Panen 5 bulan). Faktor kedua yaitu pengaruh lama penyulingan dengan tiga taraf yang terdiri atas P1 (lama penyulingan 4 jam), P2 (lama penyulingan 5 jam) dan P3 (lama penyulingan 6 jam). Kombinasi perlakuan berjumlah 9 , masing-masing kombinasi diulang tiga kali sehingga seluruhnya ada $(3 \times 3) \times 3=27$ satuan percobaan.

Variabel Pengamatan yang diamati : (1) 
tingkat kekentalan, (2) warna, (3) aroma, (4) rendemen, (5) bobot jenis, (6) kelarutan dalam alkohol 70\%, (7) kadar sitral, (8) air untuk uap, (9) bahan bakar, (10) tenaga kerja. Data dianalisis dengan menggunakan uji kontras orthogonal dan apabila terdapat perbedaan diantara faktor yang dicoba, maka analisis dilanjutkan dengan uji BNT 5\%.

\section{HASIL DAN PEMBAHASAN}

Matriks hasil analisis data penelitian pengaruh umur panen terhadap hasil minyak atsiri sereh wangi (Cymbopogon nardus $L$ ) disajikan pada tabel 1. Perhitungan angka rata-rata dan analisis statistik data komponen umur panen dan lama penyulingan disajikan pada tabel 2 dan 3. Angka rata-rata pengaruh interaksi antara umur panen dan lama penyulingan pada hasil minyak atsiri sereh wangi dapat dilihat pada tabel 4 dan 5 .

Tabel 1. Matriks Hasil Analisis Pengaruh Umur Panen dan Lama Penyulingan Terhadap Hasil Minyak Atsiri Sereh Wangi.

\begin{tabular}{|c|c|c|c|c|}
\hline \multirow{2}{*}{ No. } & \multirow{2}{*}{ Variabel yang diamati } & \multicolumn{3}{|c|}{ Faktor yang dicoba } \\
\hline & & Umur panen & Lama penyulingan & Interaksi \\
\hline 1 & Tingkat kekentalan (sekon) & tn & $\star \star \star *$ & ** \\
\hline 2 & Warna & ** & tn & ** \\
\hline 3 & Aroma & tn & * & * \\
\hline 4 & Rendemen (\%) & tn & * & ** \\
\hline 5 & Bobot jenis & ** & tn & ** \\
\hline 6 & Kelarutan dalam alcohol $70 \%(\mathrm{ml})$ & ** & tn & ** \\
\hline 7 & Kadar sitral (\%) & tn & * & ** \\
\hline 8 & Air untuk uap (liter) & tn & ** & * \\
\hline 9 & Bahan bakar (Rp) & tn & ** & * \\
\hline
\end{tabular}

Keterangan:

${ }^{* *}$ : Berbeda sangat nyata, ${ }^{*}$ : Berbeda nyata, tn : Tidak berbeda nyata

\section{Pengaruh umur panen sereh wangi}

Hasil penelitian menunjukan bahwa umur panen berbeda sangat nyata terhadap variabel warna, bobot jenis dan kelarutan dalam alkohol $70 \%$ pada variabel warna hasil penelitian menunjukkan bahwa umur panen sereh wangi berbeda sangat nyata terhadap warna minyak atsiri sereh wangi. Umur panen yang paling baik adalah umur panen 4 bulan (U2) yang mempunyai warna kuning menurut penilaian organoleptik dengan skor 1,42 kemudian umur panen 5 bulan (U3) mempunyai warna kuning dengan dengan skor 1,54 dan terendah umur panen 3 bulan (U1) dengan warna kuning tua dengan skor 2,00 . Perbedaan ini disebabkan oleh kandungan bahan aktif yang terdapat didalam tanaman, umur tanaman dan alat yang digunakan. Umumnya warna minyak yang lebih muda lebih disukai daripada warna minyak yang gelap. Standar Nasional Indonesia untuk warna minyak yang memenuhi syarat yaitu kuning muda sampai coklat tua. Secara visual, warna minyak sereh wangi hasil penelitian yang paling bagus adalah kuning jernih. Warna kuning ini berasal dari zat warna alami pada minyak atsiri sereh wangi yang dihasilkan oleh senyawa geraniol (BSN, 2006).

Hasil Penelitian menunjukkan bahwa umur panen sereh wangi berbeda sangat nyata pada variabel bobot jenis minyak atsiri sereh wangi. Umur panen yang mempunyai bobot jenis paling berat terdapat pada tanaman sereh wangi umur 3 bulan yaitu $8,53 \mathrm{~g} / 10 \mathrm{ml}$ minyak atsiri dan urutan paling berat selanjutnya adalah umur panen 4 bulan dan 5 bulan yaitu $8,44 \mathrm{~g}$ dan $8,21 \mathrm{~g}$. Bobot jenis minyak atsiri yang dihasilkan dari penyulingan tergantung dari umur panen tanaman (BSN, 2006). Menurut SNI No.063995-1995 kisaran berat jenis minyak atsiri sereh wangi adalah 0,869-0,892. Minyak atsiri yang diekstrak dari seluruh perlakuan umur panen tidak ada yang memenuhi SNI. Menurut Ketaren (1985) pemanenan tiap umur 3 bulan akan menjadikan tanaman sereh wangi bertahan lebih lama dan menghasilkan mutu minyak atsiri menjadi lebih baik. Faktor lain yang mempengaruhi 
mutu minyak atsiri antara lain: keadaan tanah, iklim, dan ketinggian tempat. Nilai bobot jenis dipengaruhi salah satunya oleh kandungan kadar air tanaman tersebut. Bagian batang mempunyai kadar air lebih tinggi dari daun. Bobot jenis minyak tidak memenuhi SNI dikarenakan saat penelitian sering terjadi hujan yang mengakibatkan tanaman sereh wangi berkadar air tinggi. Umur panen 3 bulan mempunyai bobot jenis tertinggi karena umur panen 4 dan 5 bulan lebih banyak mengandung batang. Pada bagian batang sereh wangi mengandung senyawa citronella yang lebih tinggi dari pada daun yang menyebabkan bobot jenis menjadi lebih ringan (Guenther, 1987).

Tabel 2. Angka Rata-rata dan Analisis statistik data Percobaan Umur panen dan Lama penyulingan

\begin{tabular}{llllll}
\hline Perlakuan & $\begin{array}{l}\text { Tingkat } \\
\text { kekentalan } \\
\text { (sekon) }\end{array}$ & Warna & Aroma & $\begin{array}{l}\text { Rendemen } \\
(\%)\end{array}$ & Bobot jenis \\
\hline Umur Panen & 28,40 & $2,00 \mathrm{c}$ & 1,83 & 0,33 & $8,53 \mathrm{c}$ \\
3 bulan & 27,82 & $1,42 \mathrm{a}$ & 1,59 & 0,33 & $8,44 \mathrm{~b}$ \\
4 bulan & 27,42 & $1,54 \mathrm{ab}$ & 1,67 & 0,32 & $8,21 \mathrm{a}$ \\
5 bulan & 2,42 & $24,36^{* *}$ & 2,02 & 0,48 & $159,84^{* *}$ \\
\hline F Hitung & 3,63 & 3,63 & 3,63 & 3,63 & 3,63 \\
F Tabel 5\% & 6,32 & 6,23 & 6,23 & 6,23 & 6,23 \\
F Tabel 1\% & 1,64 & 0,32 & 0,45 & 0,09 & 0,07 \\
\hline BNT 5\% & 3,40 & 11,28 & 15,29 & 6,46 & 0,46 \\
\hline KK & & & & & \\
\hline Lama Penyulingan & $26,80 \mathrm{a}$ & 1,54 & $1,51 \mathrm{a}$ & $0,31 \mathrm{a}$ & 8,39 \\
4 jam & $28,13 \mathrm{~b}$ & 1,70 & $1,73 \mathrm{~b}$ & $0,33 \mathrm{ab}$ & 8,38 \\
5 jam & $28,71 \mathrm{c}$ & 1,72 & $1,86 \mathrm{bc}$ & $0,34 \mathrm{~b}$ & 8,42 \\
\hline 6 jam & $9,60^{* *}$ & 2,59 & $4,31^{*}$ & $5,72^{*}$ & 1,78 \\
\hline F Hitung & 3,63 & 3,63 & 3,63 & 3,63 & 3,63 \\
F Tabel 5\% & 6,23 & 6,23 & 6,23 & 6,23 & 6,23 \\
\hline F Tabel 1\% & 1,64 & 0,32 & 0,45 & 0,09 & 0,07 \\
\hline BNT 5\% & 3,40 & 11,28 & 15,29 & 6,46 & 0,46 \\
\hline KK & & & & & \\
\hline Kengan & & & & &
\end{tabular}

Keterangan:

Angka-angka dalam kolom dan perlakuan yang diikuti dengan huruf yang sama menunjukkan tidak berbeda nyata berdasarkan Uji BNT pada taraf $5 \% .{ }^{* *}=$ Berbeda sangat nyata, ${ }^{*}=$ Berbeda nyata, $\mathrm{tn}=$ Tidak berbeda nyata.

Hasil Penelitian menunjukkan bahwa umur panen sereh wangi berbeda sangat nyata terhadap variabel kelarutan dalam alcohol $70 \%$. Umur panen yang mempunyai kelarutan terbaik terdapat pada tanaman sereh wangi umur 4 bulan yaitu $1 \mathrm{ml}$ minyak atsiri/3,16 ml alcohol 70\%, kemudian 5 bulan $1 \mathrm{ml}$ minyak atsiri/ $2,87 \mathrm{ml}$ alcohol $70 \%$, dan terendah terdapat pada umur panen 3 bulan yaitu $1 \mathrm{ml}$ minyak atsiri / 2,34 ml alcohol $70 \%$.

Minyak atsiri dapat larut dalam alkohol pada perbandingan dan konsentrasi tertentu, dengan demikian dapat diketahui jumlah dan konsentrasi alkohol yang dibutuhkan untuk melarutkan secara sempurna sejumlah minyak. Minyak yang mengandung senyawa terpen dalam jumlah besar akan sulit larut
(Harris, 1994). Umur panen 4 dan 5 bulan lebih banyak mengandung sitronella dari pada umur 3 bulan. Semakin tinggi bobot jenis semakin banyak kelarutanya, karena senyawa terpen yang terkandung mempunyai sifat tidak mudah larut (Sebayang, 2011). Menurut SNI No.06-3995-1995 kisaran kelarutan setiap $1 \mathrm{ml}$ minyak atsiri sereh wangi yaitu $2 \mathrm{ml}$ alkohol.

\section{Pengaruh lama penyulingan sereh wangi}

Hasil analisis menunjukkan bahwa lama penyulingan tanaman sereh wangi memperlihatkan pengaruh yang berbeda sangat nyata terhadap tingkat kekentalan minyak atsiri sereh wangi. Lama penyulingan terbaik (paling cair), yaitu pada lama penyulingan 4 jam yaitu 26,80 (s/100ml), kemudian lama penyulingan 5 jam yaitu 28,13 
(s/100ml), dan terlama pada lama penyulingan 6 jam 28,71 (s/100ml). Perbedaan ini disebabkan oleh bobot jenis penyulingan 4 jam lebih ringan dibandingkan lama penyulingan 5 dan 6 jam.

Tabel 3. Angka Rata-rata dan Analisis statistik data Percobaan Umur panen dan Lama penyulingan

\begin{tabular}{|c|c|c|c|c|}
\hline Perlakuan & $\begin{array}{l}\text { Kelarutan dalam } \\
\text { alkohol } \\
(\mathrm{ml})\end{array}$ & $\begin{array}{l}\text { Kadar sitral } \\
(\%)\end{array}$ & $\begin{array}{l}\text { Banyaknya air untuk } \\
\text { uap } \\
\text { (liter) }\end{array}$ & $\begin{array}{l}\text { Bahan bakar } \\
\text { (Rp) }\end{array}$ \\
\hline \multicolumn{5}{|l|}{ Umur Panen } \\
\hline 3 bulan & $3,16 \mathrm{c}$ & 32,28 & 563,33 & 34277 \\
\hline 4 bulan & $2,87 \mathrm{~b}$ & 31,39 & 553,44 & 33333 \\
\hline 5 bulan & $2,34 \mathrm{a}$ & 32,11 & 565,33 & 34722 \\
\hline F Hitung & $6,43^{\star *}$ & 0,39 & 1,46 & 2,04 \\
\hline F Tabel 5\% & 3,63 & 3,63 & 3,63 & 3,63 \\
\hline F Tabel $1 \%$ & 6,23 & 6,23 & 6,23 & 6,23 \\
\hline BNT 5\% & 0,85 & 3,90 & 27,36 & 2914,85 \\
\hline $\mathrm{KK}$ & 17,67 & 7,06 & 2,82 & 4,92 \\
\hline \multicolumn{5}{|c|}{ Lama Penyulingan } \\
\hline 4 jam & 7,69 & $33,00 \mathrm{c}$ & 463,33 a & 26388,89 a \\
\hline 5 jam & 7,72 & $32,61 \mathrm{~b}$ & $563,11 b$ & 35277,78 b \\
\hline 6 jam & 8,32 & $30,17 \mathrm{a}$ & $655,67 \mathrm{c}$ & $41111,11 \mathrm{c}$ \\
\hline F Hitung & 0,15 & $5,33^{*}$ & $333,22^{\star *}$ & $174,45^{\star \star}$ \\
\hline F Tabel 5\% & 3,63 & 3,63 & 3,63 & 3,63 \\
\hline F Tabel $1 \%$ & 6,23 & 6,23 & 6,23 & 6,23 \\
\hline BNT 5\% & 0,85 & 3,90 & 27,36 & 2914,85 \\
\hline $\mathrm{KK}$ & 17,67 & 7,06 & 2,82 & 4,92 \\
\hline
\end{tabular}

Keterangan:

Angka-angka dalam kolom dan perlakuan yang diikuti dengan huruf yang sama menunjukkan tidak berbeda nyata berdasarkan Uji BNT pada taraf $5 \% .{ }^{* *}=$ Berbeda sangat nyata, ${ }^{*}=$ Berbeda nyata, $\mathrm{tn}=$ Tidak berbeda nyata.

Ariyanti dan Agus (2010) menyatakan kekentalan suatu fluida yang menyatakan besar kecilnya gesekan dalam fluida. Semakin besar viskositas fluida, maka semakin sulit suatu fluida untuk mengalir dan juga menunjukan semakin sulit suatu benda bergerak dalam fluida tersebut. Kekentalan merupakan sifat cairan yang berhubungan dengan hambatan mengalir. Tingkat kekentalan sesuai dengan variabel pengamatan bobot jenis yang menujukan semakin berat semakin lama daya alirnya. Semakin lama penyulingan bobot jenisnya semakin kecil sampai batas lama penyulingan 4,5 jam, dan akan naik pada lama penyulingan 5 jam. Semakim turunya bobot jenis sampai batas lama penyulingan 4,5 jam disebabkan oleh semakin naiknya kadar geraniol dan sitronellal sampai lama penyulingan 4,5 jam. Geraniol dan Sitronella merupakan petunjuk kemurnian minyak sereh wangi. jadi semakin banyaknya geraniol dan sitronella minyak tersebut semakin murni (Ginting, 2004). Hasil analisis menunjukkan bahwa lama penyulingan tanaman sereh wangi memperlihatkan pengaruh berbeda nyata terhadap aroma minyak atsiri sereh wangi. Lama penyulingan yang mempunyai aroma terkuat adalah lama penyulingan 6 jam yaitu mempunyai aroma ekstrak lemon 2 sedangkan lama penyulingan 4 jam dan 5 jam mempunyai aroma ekstrak lemon 1. Perbedaan ini disebabkan oleh sitronellal yaitu senyawa yang menentukan aroma khas pada minyak sereh wangi, kadarnya paling tinggi pada awal distilasi yaitu sebesar $63,43 \%$ pada jam pertama dan $15,75 \%$ pada jam ke-4 distilasi, oleh karena itu minyak sereh dengan kadar sitronella yang tinggi akan lebih digemari (Ginting, 2004).

Hasil analisis menunjukkan bahwa lama penyulingan tanaman sereh wangi memperlihatkan pengaruh yang berbeda nyata terhadap rendemen minyak atsiri sereh wangi. Lama penyulingan yang mempunyai rendemen tertinggi adalah lama penyulingan 6 jam 0,34 \%, sedangkan lama penyulingan 5 jam dan 4 jam sebanyak 0,33\% dan 0,31 $\%$. Penyulingan minyak atsiri serai menggunakan sistem penyulingan uap dan air. Pemilihan sistem penyulingan ini karena bahan yang digunakan berupa daun dan batang sehingga minyak atsiri yang dihasilkan lebih banyak, penyulingan lebih sing- 
kat dan bahan yang disuling tidak menjadi gosong (Sastrohamidjojo, 2004).

Penyulingan minyak atsiri semakin lama akan menghasilkan rendemen yang lebih banyak namun hasil rendemen tidak berbeda signifikan. Beberapa penelitian telah dilakukan untuk menghasilkan minyak atsiri dengan proses distilasi, diantaranya hasil penelitian Nuryanti (2011) menunjukkan pro- ses distilasi pada daun kemangi selama 3, 4, 5 jam masih menunjukkan penambahan rendemen minyak atsiri. Pada distilasi minyak atsiri daun sereh wangi (Ginting, 2004) menunjukkan bahwa waktu proses 4 jam menghasilkan rendemen minyak atsiri sereh wangi tertinggi dan tidak berbeda secara signifikan dengan 5 dan 6 jam.

Tabel 4. Angka Rata-rata Pengaruh Interaksi Antara Umur Panen dan Lama Penyulingan.

\begin{tabular}{llllll}
\hline Perlakuan & $\begin{array}{l}\text { Tingkat kekentalan } \\
\text { (sekon) }\end{array}$ & Warna & Aroma & $\begin{array}{l}\text { Rendemen } \\
(\%)\end{array}$ & Bobot jenis \\
\hline U1P1 & $26,27 \mathrm{a}$ & $1,92 \mathrm{de}$ & $1,65 \mathrm{ab}$ & $1,32 \mathrm{a}$ & $8,54 \mathrm{de}$ \\
U1P2 & $27,87 \mathrm{ab}$ & $2,17 \mathrm{e}$ & $1,88 \mathrm{~b}$ & $1,34 \mathrm{a}$ & $8,50 \mathrm{cde}$ \\
U1P3 & $31,07 \mathrm{c}$ & $1,92 \mathrm{de}$ & $1,97 \mathrm{c}$ & $1,34 \mathrm{a}$ & $8,56 \mathrm{e}$ \\
U2P1 & $27,07 \mathrm{a}$ & $1,22 \mathrm{a}$ & $1,40 \mathrm{a}$ & $1,31 \mathrm{a}$ & $8,45 \mathrm{c}$ \\
U2P2 & $29,20 \mathrm{~b}$ & $1,30 \mathrm{ab}$ & $1,53 \mathrm{ab}$ & $1,34 \mathrm{a}$ & $8,41 \mathrm{c}$ \\
U2P3 & $27,20 \mathrm{a}$ & $1,73 \mathrm{~cd}$ & $1,85 \mathrm{~b}$ & $1,34 \mathrm{a}$ & $8,46 \mathrm{~cd}$ \\
U3P1 & $27,07 \mathrm{a}$ & $1,48 \mathrm{abc}$ & $1,47 \mathrm{ab}$ & $1,30 \mathrm{a}$ & $8,17 \mathrm{a}$ \\
U3P2 & $27,33 \mathrm{a}$ & $1,63 \mathrm{bcd}$ & $1,77 \mathrm{ab}$ & $1,33 \mathrm{a}$ & $8,25 \mathrm{~b}$ \\
U3P3 & $27,87 \mathrm{ab}$ & $1,52 \mathrm{abc}$ & $1,77 \mathrm{ab}$ & $1,34 \mathrm{a}$ & $8,23 \mathrm{ab}$ \\
\hline F Hitung & $11,82^{\star *}$ & $7,43^{* *}$ & $4,38^{\star *}$ & $7,09^{* *}$ & $7,08^{\star *}$ \\
F Tabel 5\% & 3,01 & 3,01 & 3,01 & 3,01 & 3,01 \\
F Tabel 1\% & 4,77 & 4,77 & 4,77 & 4,77 & 4,77 \\
\hline BNT 5\% & 1,64 & 0,32 & 0,45 & 0,10 & 0,07 \\
\hline KK & 3,40 & 11,28 & 15,29 & 6,46 & 0,46 \\
\hline KK & & & & &
\end{tabular}

Keterangan:

Angka-angka dalam kolom dan perlakuan yang diikuti dengan huruf yang sama menunjukkan tidak berbeda nyata berdasarkan Uji BNT pada taraf $5 \% .{ }^{* *}=$ Berbeda sangat nyata, ${ }^{*}=$ Berbeda nyata, $\mathrm{tn}=$ Tidak berbeda nyata.

Hasil analisis menunjukkan bahwa lama penyulingan pada tanaman sereh wangi memperlihatkan pengaruh yang berbeda sangat nyata terhadap kadar sitral minyak atsiri sereh wangi. Lama penyulingan yang mempunyai persentase kadar sitral tertinggi adalah lama penyulingan 4 jam yaitu $33,00 \%$, kemudian lama penyulingan 5 jam adalah $32,61 \%$ dan terendah lama penyulingan 6 jam yaitu 30,17 . Sitral merupakan senyawa yang mempunyai titik didih rendah yaitu 205$208^{\circ} \mathrm{C}$, kandungan sitral akan menurun pada akhir destilasi (jam ke 4 atau 6 jam setelah pengapian) karena semakin lama waktu penyulingan maka jumlah minyak perjam yang dihasilkan lebih sedikit dan sebaliknya semakin pendek waktu penyulingan maka semakin banyak minyak perjam yang dihasilkan (Sari dan Chairul, 2005).

Kandungan sitral dalam kemangi mencapai $70 \%$ minyak atsiri kemangi dalam penelitian ini menggunakan analisa GC-MS dan didapatkan kadar terbesar $69,21 \%$ pada variabel waktu 120 menit dan suhu $35^{\circ} \mathrm{C}$, komponen utama adalah Z-citral (3,7 dimetil2,6-octadienal), E-citral (CAS), Neral. Sedangkan kadar sitral terkecil yaitu 36,76\% terdapat pada waktu 150 menit dan suhu $45^{\circ} \mathrm{C}$ (Daryono dkk, 2014).

\section{Pengaruh interaksi umur panen dan lama penyulingan}

Hasil Penelitian menunjukan bahwa interaksi antara umur panen dengan lama penyulingan berbeda sangat nyata terhadap variabel tingkat kekentalan, warna, rendemen, bobot jenis minyak, kelarutan dalam alcohol, kadar sitral dan berbeda nyata terhadap variabel aroma, bahan bakar dan air untuk uap. Interaksi terbaik diperoleh pada kombinasi perlakuan umur panen 3 bulan dan lama penyulingan 5 jam.

Interaksi ini terjadi karena umur panen 3 bulan dan lama penyulingan 5 jam adalah umur panen dan lama penyulingan yang optimal. Jika tanah cukup subur pemanenan sereh wangi dapat dilakukan tiap-tiap 3 
bulan, tanaman yang terlalu muda menghasilkan rendemen dan mutu minyak yang rendah dan pemanenan yang terlalu tua menyebabkan daun berwarna coklat akan kehilangan sebagian minyak oleh pengaruh panas dan cuaca. Pemanenan sebaiknya dilakukan pada pagi hari atau menjelang malam ,dan jangan pada siang hari ,untuk mendapatkan kadar minyak yang tinggi (Ketaren, 1985). Hal ini sependapat dengan hasil penelitian Jaelani (2014) menunjukan bahwa bagian tanaman nilam berbeda sangat nyata terhadap berat jenis. Berat jenis minyak yang dihasilkan dari penyulingan nilam tergantung dari bagian tanaman yang disuling dan lama penyulingan. Makin banyak daun tanaman yang disuling dan semakin efisiensi waktu penyulingan, maka semakin tinggi pula berat jenis yang dihasilkan (Guenther, 1972).

Tabel 5. Angka Rata-rata Pengaruh Interaksi Antara Umur Panen dan Lama Penyulingan.

\begin{tabular}{lllll}
\hline Perlakuan & $\begin{array}{l}\text { Kelarutan } \\
(\mathrm{ml})\end{array}$ & $\begin{array}{l}\text { Kadar sitral } \\
(\%)\end{array}$ & $\begin{array}{l}\text { Air untuk uap } \\
(\text { liter })\end{array}$ & $\begin{array}{l}\text { Bahan bakar } \\
(\mathrm{Rp})\end{array}$ \\
\hline U1P1 & $3,27 \mathrm{ab}$ & $34,17 \mathrm{a}$ & $465,33 \mathrm{~b}$ & $26667 \mathrm{a}$ \\
U1P2 & $3,08 \mathrm{ab}$ & $34,00 \mathrm{a}$ & $571,00 \mathrm{~d}$ & $35833 \mathrm{~b}$ \\
U1P3 & $3,13 \mathrm{ab}$ & $30,33 \mathrm{a}$ & $655,00 \mathrm{f}$ & $41667 \mathrm{~d}$ \\
U2P1 & $2,67 \mathrm{ab}$ & $32,17 \mathrm{a}$ & $416,67 \mathrm{a}$ & $25833 \mathrm{a}$ \\
U2P2 & $2,83 \mathrm{ab}$ & $32,33 \mathrm{a}$ & $524,00 \mathrm{c}$ & $34167 \mathrm{~b}$ \\
U2P3 & $3,10 \mathrm{ab}$ & $31,67 \mathrm{a}$ & $624,33 \mathrm{e}$ & $40000 \mathrm{c}$ \\
U3P1 & $2,30 \mathrm{a}$ & $31,67 \mathrm{a}$ & $471,33 \mathrm{~b}$ & $26667 \mathrm{a}$ \\
U3P2 & $2,37 \mathrm{a}$ & $31,50 \mathrm{a}$ & $565,00 \mathrm{~d}$ & $35833 \mathrm{~b}$ \\
U3P3 & $2,35 \mathrm{a}$ & $30,83 \mathrm{a}$ & $659,67 \mathrm{f}$ & $41667 \mathrm{ed}$ \\
\hline F Hitung & $4,98^{* *}$ & $6,41^{* *}$ & $4,71^{* *}$ & $4,12^{* *}$ \\
F Tabel 5\% & 3,01 & 3,01 & 3,01 & 3,01 \\
F Tabel 1\% & 4,77 & 4,77 & 4,77 & 4,77 \\
\hline BNT 5\% & 0,85 & 3,90 & 27,36 & 2914,85 \\
\hline KK & 17,67 & 7,06 & 2,82 & 4,92 \\
\hline Ke & & &
\end{tabular}

Keterangan:

Angka-angka dalam kolom dan perlakuan yang diikuti dengan huruf yang sama menunjukkan tidak berbeda nyata berdasarkan Uji BNT pada taraf $5 \% .{ }^{* \star}=$ Berbeda sangat nyata, ${ }^{*}=$ Berbeda nyata, $\mathrm{tn}=$ Tidak berbeda nyata.

Beberapa penelitian telah dilakukan untuk menghasilkan minyak atsiri dengan proses destilasi, diantaranya hasil penelitian Nuryanti (2011) menunjukkan proses distilasi pada daun kemangi selama 3, 4, 5 jam masih menunjukkan penambahan rendemen minyak atsiri. Pada distilasi minyak atsiri daun sereh wangi (Ginting, 2004) menunjukkan bahwa waktu proses 4 jam menghasilkan rendemen minyak atsiri sereh wangi tertinggi dan tidak berbeda secara signifikan dengan 5 dan 6 jam. Berdasarkan pengalaman pada penyulingan 4,5 jam akan menghasilkan minyak sereh wangi dengan kadar geraniol maksimum $85 \%$ dan sitronella 35\%. Dengan demikian penyulingan diatas 4,5 jam (5-6) jam tidak akan menambah kadar kedua zat tersebut. Lama penyulingan tergantung dari tekanan uap yang dipergunakan dan faktor kondisi terutama kadar air daun sereh (Sebayang, 2011). Sitral merupakan senyawa yang mempunyai titik didih rendah yaitu $205-208^{\circ} \mathrm{C}$, kandungan sitral akan menurun pada akhir destilasi (jam ke 4 atau 6 jam setelah pengapian) karena semakin lama waktu penyulingan maka jumlah minyak perjam yang dihasilkan lebih sedikit dan sebaliknya semakin pendek waktu penyulingan maka semakin banyak minyak perjam yang dihasilkan (Sari dan Chairul, 2005).

\section{KESIMPULAN}

1. Umur panen 3 bulan memberikan kualitas dan hasil rendemen minyak atsiri sereh wangi tertinggi.

2. Lama penyulingan yang paling efsien dan memberikan hasil yang terbaik yaitu lama penyulingan 5 jam (P2). 
3. Terdapat interaksi antara umur panen dan lama penyulingan pada seluruh variabel. Interaksi terbaik yaitu umur panen 3 bulan dan lama penyulingan 5 jam (U1P2).

\section{DAFTAR PUSTAKA}

Ambarwati R.A. 2011 Deteksi Adanya Pemalsuan Minyak Sereh Dengan Menguji Putaran Optik Menggunakan Polarimeter Tipe Atago 2l (diakses tanggal 15 Desember 2016 eprints.undip.ac.id/32142/1/R._AJENG _ AMBARWATI.pdf).

Anantyo D.T. 2009. Efek Minyak Atsiri dari Bawang Putih Terhadap Persentase Jumlah Neutrofil Tikus Wistar yang Diberi Diet Kuning Telur. Skripsi. Fakultas Kedokteran UNDIP Semarang. http://eprints.undip.ac.id/7592/.

Ariyanti E.S dan Agus M. 2010. Otomasasi Pengukuran Koefisien Viskositas Zat Cair Menggunakan Gelombang Ultrasonik. Jurnal Neutrino. vol 2. No 2.

BSN. 2006. Spesifikasi Persyaratan Mutu Minyak Nilam.

Daryono E.D dan Isnaini A. 2014. Ekstraksi Minyak Atsiri Pada Tanaman Kemangi Dengan Pelarut Heksana. Jurnal Teknik Kimia Vol.9. No.1.

Ginting S.2004. Pengaruh Lama Penyulingan Terhadap Rendemen dan Mutu Minyak Atsiri Daun Sereh Wangi. Fakultas Pertanian. Universitas Sumatera Utara.

Guenther, E., (1987), Minyak Atsiri (Jilid I) terjemahan S.Ketaren. Penerbit Universitas Indonesia: Jakarta.

Harris, R, 1987. Tanaman Minyak Atsiri, Penebar Swadaya. Jakarta. 1994; 4 Jaelani A. 2014. Pengaruh Pelarut dan Bagian Tanaman Terhadap Kualitas dan Kuantitas Minyak Atsiri Nilam (Pogostemon cablin Benth). Skripsi Fakultas Pertanian. Universitas Pekalongan. Tidak Dipublikasikan.

Ketaren S. 1985. Pengantar Teknologi Minyak Atsiri. PN.Balai Pustaka.
Mansur, M dan Laksamanaharja 1987. Plasma Nutfah Sereh Wangi. Edisi khusus Penelitian Tanaman Rempah dan Obat. Vol 3 (1): 38-46.

Novalny, D. 2006. Pengaruh Ukuran Rajangan dan Lama PenyulinganTerhadap Rendemen dan Karakteristik Minyak Sirih (Piper betle). Skripsi. Institut Pertanian Bogor. Bogor. https://core.ac.uk/download/ pdf/32339867.pdf.

Noviarso, C. 2003. Pengaruh Umu Panen dan Masa Simpan Buah Sukun (Artocarpus altilis) Terhadap Kualitas Tepung sukun Yang Dihasilkan. Skripsi. Institut Pertanian Bogor. Bogor. $\quad$ http://repository.ipb.ac.id/ bitstream/handle/123456789/18296/FO 3cno.pdf.

Nuryanti. 2011. Pengaruh Lama Penyulingan Terhadap Rendemen Minyak Kemangi yang Dihasilkan Dengan Metode Destilasi. Tugas Akhir Univrsitas Diponegoro Semarang.

Richards, W. F. Perfumer's Hand Book and Catalog, New York:Fritzsche Brother Inc (1944).

Rosman R. 2012. Kesesuaian lahan dan iklim tanamanserai wangi. Bunga Rampai Inovasi Tanaman Atsiri Indonesia. Badan Litbang Pertanian. Kementerian Pertanian. Jakarta. pp. 65-70.

Santoso H.B.1992. Sereh Wangi Bertanam dan Penyulingan. KANISIUS, Yogyakarta.

Sari D.I dan Chairul. 2005. Penentuan Waktu Penyulingan dari Sereh Wangi (Cymbopogon nardus L) Untuk Memperoleh Kadar Maksimal Minyak Atsiri. Media Litbang Kesehatan Vol XV Nomor 4. Th. 2005.

Sastrohamidjojo. H. 2004. Minyak Atsiri. Gadjah Mada University Press Yogyakarta.

Sebayang E.P. 2011. Pengendalian Mutu Minyak Atsiri Sereh Wangi (Citronella oil) di UKM Sari Murni (diakses tanggal 20 Desember 2016, 
http://eprints.uns.ac.id/502/1/2/206971 411201101111.pdf).

Suryani. H dan Muhartini. S. 2013. Pertumbuhan, Hasil dan Mutu Minyak Atsiri 16 Aksesi Nilam (Pogostemon cablin Benth.) Dipanen pada Umur yang Berbeda. (diakses pada 10 juli 2017

https://journal.ugm.ac.id/index.php/ibp/
article/viewFile/1384/pdf 18).

Wartini. N.M.2007. Komparasi Metode Separasi dan Pengaruh Curing Terhadap Komposisi Senyawa Dalam Ekstrak Flavour Daun Salam (Eugemia Polyantha Wight). Desertasi tidak dipublikasikan. Program Pascasarjana Fakultas Pertanian Universitas Brawijaya Malang. 